\title{
Mapping carbon sequestration in forests at the regional scale - a climate biomonitoring approach by example of Germany
}

Winfried Schröder ${ }^{\dagger}$ and Roland Pesch ${ }^{*+}$

\begin{abstract}
Background: The United Nations Framework Convention on Climate Change recognizes carbon (C) fixation in forests as an important contribution for the reduction of atmospheric pollution in terms of greenhouse gases. Spatial differentiation of $C$ sequestration in forests either at the national or at the regional scale is therefore needed for forest planning purposes. Hence, within the framework of the Forest Focus regulation, the aim of this investigation was to statistically analyse factors influencing the $C$ fixation and to use the corresponding associations in terms of a predictive mapping approach at the regional scale by example of the German federal state North Rhine-Westphalia. The results of the methodical scheme outlined in this article should be compared with an already-published approach applied to the same data which were used in the investigation at hand.
\end{abstract}

Methods: Site-specific data on C sequestration in humus, forest trees/dead wood and soil from two forest monitoring networks were intersected with available surface information on topography, soil, climate and forestal growing areas and districts. Next, the association between the $\mathrm{C}$ sequestration and the influence factors were examined and modelled by linear regression analyses. The resulting regression equations were applied on the surface data to predicatively map the $C$ sequestration for the entire study area.

Results: The computations yielded an estimation of 146.7 mio t $C$ sequestered in the forests of North RhineWestphalia corresponding to $168.6 \mathrm{t} / \mathrm{ha}$. The calculated values correspond well to according specifications given by the literature. Furthermore, the results are almost identical to those of another pilot study where a different statistical methodology was applied on the same database. Nevertheless, the underlying regression models contribute only a low degree of explanation to the overall variance of the $\mathrm{C}$ fixation. This might mainly be due to data quality aspects and missing influence factors in the analyses.

Discussion: In another study, an alternative approach was introduced to map the spatial differentiation of $C$ sequestration in North Rhine-Westphalia based on the combination of geostatistics, decision tree analyses and GIS techniques. As a result, the overall mean of $C$ sequestration amounted for $177 \mathrm{t} \mathrm{C/ha} \mathrm{which} \mathrm{is} 8.4 \mathrm{t}$ C/ha higher than what was calculated in the study at hand and $14 \mathrm{t} C /$ ha below the roughly guessed German-wide mean of 191 t C/ha.

Conclusions: The surface estimations of $\mathrm{C}$ pools in living forest trees/dead wood, the humus layer and the mineral soil enable to map the fixation of the greenhouse gas $\mathrm{CO}_{2}$ in forests at the regional scale. The estimations that were derived in this study are in good accordance with estimations based on techniques which, in contrast, did neither allow for spatial differentiation nor for mapping. The presented approach should be validated by application of other statistical techniques and by use of German wide inventory data. Furthermore, $C$ sequestration should be modelled according to different climate change scenarios by combining statistical methods and dynamic modelling.

\footnotetext{
* Correspondence: rpesch@iuw.uni-vechta.de

† Contributed equally

Chair of Landscape Ecology, University of Vechta, PO Box. 1553, 49364

Vechta, Germany
} 


\section{Background}

According to the International Panel for Climatic Change most of the observed increase in global average air temperatures since the last century is most likely caused by an increase of atmospheric concentrations of greenhouse gases like carbon dioxide $\left(\mathrm{CO}_{2}\right)$, methane $\left(\mathrm{CH}_{4}\right)$ and nitrous oxide $\left(\mathrm{N}_{2} \mathrm{O}\right)$ [1]. Greenhouse gases warm the atmosphere by absorbing thermal infrared radiation that is emitted by the earth's surface or by the atmosphere itself. Accordingly, compared with preindustrial times the global mean temperature increased by $0.8^{\circ} \mathrm{C}$ for land and oceans, and by $1.0^{\circ} \mathrm{C}$ for land alone [1]. Temperatures in Europe have increased even more than the global average $\left(1.0^{\circ} \mathrm{C}\right.$ and $1.2^{\circ} \mathrm{C}$, respectively), especially in the southwest, the northeast and in mountainous regions [2]. Projections suggest further temperature increases in Europe between $1.0^{\circ} \mathrm{C}$ and $5.5^{\circ}$ $\mathrm{C}$ by the end of this century, which is also higher than temperatures expected for the entire world $\left(1.8^{\circ} \mathrm{C}\right.$ to $4.0^{\circ}$ C) [2]. Furthermore, 11 of the 12 years between 1995 and 2006 were the warmest since the first temperature measurements performed in 1850. With an increase of $0.13^{\circ} \mathrm{C}\left( \pm 0.03^{\circ} \mathrm{C}\right)$ per decade in the preceding 50 years the temperature rise is almost double to that of the last 100 years.

Although it is often difficult to distinguish between impacts of medium and long-term climate change on forestry and agriculture and influences related to the management of forests and crops, there is growing evidence that processes such as changes in phenology $[3,4]$, length of growing seasons [5,6] and northwards shift of crops and forest species [7] relate to climate change [1]. Forests contain $77 \%$ of the global C pool in vegetation biomass which underlines their important role in the global $\mathrm{C}$ cycle $[8,1]$. The flux of $\mathrm{C}$ between the atmosphere and the land and oceans is dominated by natural processes, such as plant photosynthesis. Terrestrial $\mathrm{C}$ sequestration is the process through which atmospheric $\mathrm{CO}_{2}$ is absorbed by trees, plants and crops through photosynthesis, and stored as $\mathrm{C}$ in stems, branches, leaves, roots and soils. Thus, forests play a fundamental role in mitigating climate change because they act as sinks for $\mathrm{CO}_{2}$. However, they are also very vulnerable to changes in temperature, precipitation and extreme weather events which can have destructive impacts (e.g. tree breakage, droughts, forest fires) resulting in a reduction of the $\mathrm{C}$ sequestration potential of the forest [2, p. 135]. Additionally, climate change increases the risk of insect pests and elevation of atmospheric ozone concentrations [9]. The United Nations Framework
Convention on Climate Change therefore understands C fixation in forests as an important contribution to the reduction of greenhouse gases. With an estimated amount of 2,060 Gt $\mathrm{C}$ forests fix far less $\mathrm{C}$ than is the case for oceans $(38,000 \mathrm{Gt} \mathrm{C})$. Nevertheless, there is great potential in terms of the spatial expansion of forest areas and the shift of suitable forest categories [10]. The $\mathrm{C}$ flux potential of forests (2 Gt C per year) corresponds to that of the oceans and exceeds that of the atmosphere by 1 Gt $C$ per year [11].

As an additional sink for $\mathrm{C}$, soil in the EU contains around $71 \mathrm{Gt}$ of organic $\mathrm{C}$ which is nearly $10 \%$ of the $\mathrm{C}$ accumulated in the atmosphere [2]. In Canada's boreal forests, as much as $80 \%$ of the total $\mathrm{C}$ is stored in the soils as dead organic matter $[12,13]$. Low temperatures and insufficient moisture help in reducing the decomposition of dead biomass (mainly leaves, stems, roots of plants) leading to an accumulation of soil organic matter (SOM) of which organic C (SOC) is a part of. Plant residues contain $60 \%$ to $90 \%$ moisture. The remaining dry matter consists of $\mathrm{C}$, oxygen $(\mathrm{O})$, hydrogen $(\mathrm{H})$ and small amounts of sulphur $(\mathrm{S})$, nitrogen $(\mathrm{N})$, phosphorus $(\mathrm{P})$, potassium $(\mathrm{K})$, calcium $(\mathrm{Ca})$ and magnesium $(\mathrm{Mg})$ components. These include, in varying proportions and many intermediate stages, an active organic fraction including microorganisms (10\% to $40 \%$ ), and resistant or stable organic matter ( $40 \%$ to $60 \%$ ), also referred to as humus. In a given soil ecosystem, the rate of decomposition and accumulation of SOM is determined by such soil properties as texture, $\mathrm{pH}$, temperature, moisture, aeration, clay mineralogy, soil biological activities and land use. Increasing temperatures will accelerate decay rates, leading to increased $\mathrm{CO}_{2}$ and $\mathrm{CH}_{4}$ emissions from soil. SOM in turn influences or modifies many of these same soil properties $[14,15]$. Root turnover also constitutes an important addition of humus into the soil, and consequently, it is important for $\mathrm{C}$ sequestration. In forests, most organic matter is added as superficial litter. However, in grassland ecosystems, up to two thirds of organic matter is added through the decay of roots [16].

For estimating $\mathrm{C}$ stocks or stock change (flux), $\mathrm{C}$ in forest ecosystems can be divided into the following five storage pools [1]: (1) aboveground biomass including all living biomass above the soil, i.e. stem, stump, branches, bark, seeds, foliage (live understory); (2) belowground biomass, which encompasses all living biomass of coarse living roots greater than $2 \mathrm{~mm}$ diameter; (3) dead wood, which comprises all non-living woody biomass either standing, lying on the ground (but not including litter) or in the soil; (4) litter, which includes the litter, fumic 
and humic layers, and all non-living biomass with a diameter less than $7.5 \mathrm{~cm}$ at transect intersection, lying on the ground; (5) SOC, including all organic material in soil to a depth of $1 \mathrm{~m}$ but excluding the coarse roots of the aboveground pools.

Additionally, there exist two harvested wood pools that are also necessary for estimating $C$ flux: harvested wood products in use and harvested wood products in landfills [17]. Quantitative information from observations and modelling of the impacts of climate change on soil and related feedbacks is very limited. To date, assessments have relied mainly on local case studies. Indicators covering all of Europe are not available, and there is an urgent need for the establishment of appropriate monitoring schemes [2, p. 124].

In Europe, Commission Regulation (EC) No 1737/ 2006 of 7 November 2006 detailed rules for the implementation of Regulation (EC) No 2152/2003 of the European Parliament and of the council concerning monitoring of forests and environmental interactions in the community. The objective of this Forest Focus regulation was to establish a community scheme for harmonised, broad-based, comprehensive and long-term monitoring of European forest ecosystems. Amongst others, the Forest Focus programme addressed the monitoring of climate change and $\mathrm{C}$ sequestration. As part of that programme, a project was conducted aiming at the mapping of $\mathrm{C}$ sequestration at the regional scale. Thereby, the results derived by different methodical approaches applied to the same data should be compared. This paper is based on this project and deals with a climate biomonitoring method for mapping the $\mathrm{C}$ storage in humus layer, living forest trees/dead wood and mineral soil, using available forest monitoring data collected in North Rhine-Westphalia, one of 16 German federal states.

In another paper [18] from the abovementioned Forest Focus project, a combination of geostatistical methods and decision tree models was applied to map the $C$ storage throughout North Rhine-Westphalia. The $C$ storage was thereby estimated for humus, mineral soils and biomass by use of the same forest inventory data and additional geoinformation on soils, climate and altitude [18]. Whereas spatial autocorrelation could be detected for the $C$ loads in the humus layers neither the $C$ amounts in mineral soils nor in living forest trees/dead wood were spatially autocorrelated. Accordingly, a map on $\mathrm{C}$ sequestration was calculated for the humus layer in North Rhine-Westphalian forests by ordinary kriging resulting in a total amount of $19 \mathrm{t} \mathrm{C/ha}$. For mineral soils and living or dead biomass, decision tree analyses were applied leading to an amount of $90.7 \mathrm{t} \mathrm{C} /$ ha in soils and $67 \mathrm{t} \mathrm{C} /$ ha in living forest trees/dead wood. The overall mean therefore amounted for $177 \mathrm{t} \mathrm{C} / \mathrm{ha}$ in
North Rhine-Westphalia which is $14 \mathrm{t} \mathrm{C}$ /ha below the roughly guessed German-wide mean of $191 \mathrm{t} \mathrm{C/ha}$.

From the estimation of primary production and $\mathrm{C}$ sink in forests of the 25 member states of the European Union could be concluded that any individual method is prone to so much uncertainty that several, preferably independent, methods need to be used to estimate a regional C budget' [19]. The objective of this paper therefore is to apply an alternative methodology to validate the calculated results as described by [18]. The methodology relies on a combination of linear regression analysis and geostatistical methods commonly referred to as regression kriging [20,21]. The approach had already been successfully applied to map the $C$ sequestration in mineral soils of forests in the southwest of Germany [22-24].

\section{Materials and methods \\ Data}

The methodology described below was applied to the same data already used by [18]. The data were derived from two forest inventory programs: The forest inventory Landeswaldinventur (LWI) relies on a $1 \times 1-\mathrm{km}$ sampling raster across forested areas within North Rhine-Westphalia (Figure 1 left). The aim of the LWI is to assess the state and the temporal development of the stock of wood in forests down to the local scale. The LWI was performed once in 1998 providing data on the $\mathrm{C}$ loads in living forest trees/dead wood. The nationwide soil inventory Bodenzustandserhebung (BZE) was carried through first from 1989 to 1991 following the sampling raster of the UN ECE ICP Forests Level I programme with a spatial resolution of $4 \times 4 \mathrm{~km}$ (Figure 1 right). A second BZE campaign was initiated in 2006 (BZE II). The aim of this programme is to quantify the physical, chemical and biological properties of forest soils throughout Germany and to link this information to data on crown thinning of forest trees. In this way, the reasons of forest decline are to be assessed. The BZE provides information on the $C$ storage in the humus layer and the mineral soil.

Next to the site-specific BZE and LWI inventory data, digital surface maps on potentially influencing environmental factors like soil properties, land use and climate were included in the statistical analyses and the regionalisation of the $\mathrm{C}$ sequestration. The spatial extent of woodlands was derived from the official German topographic cartographic information system ATKIS. Detailed information on soil properties were taken from a soil map with a spatial resolution of 1:50,000 (Bk 50): These include data on soil types and texture, soil productivity, depth of upper soil layer, effective root zone, available field capacity, cation exchange capacity, water conductivity and soil wetness. To account for the 

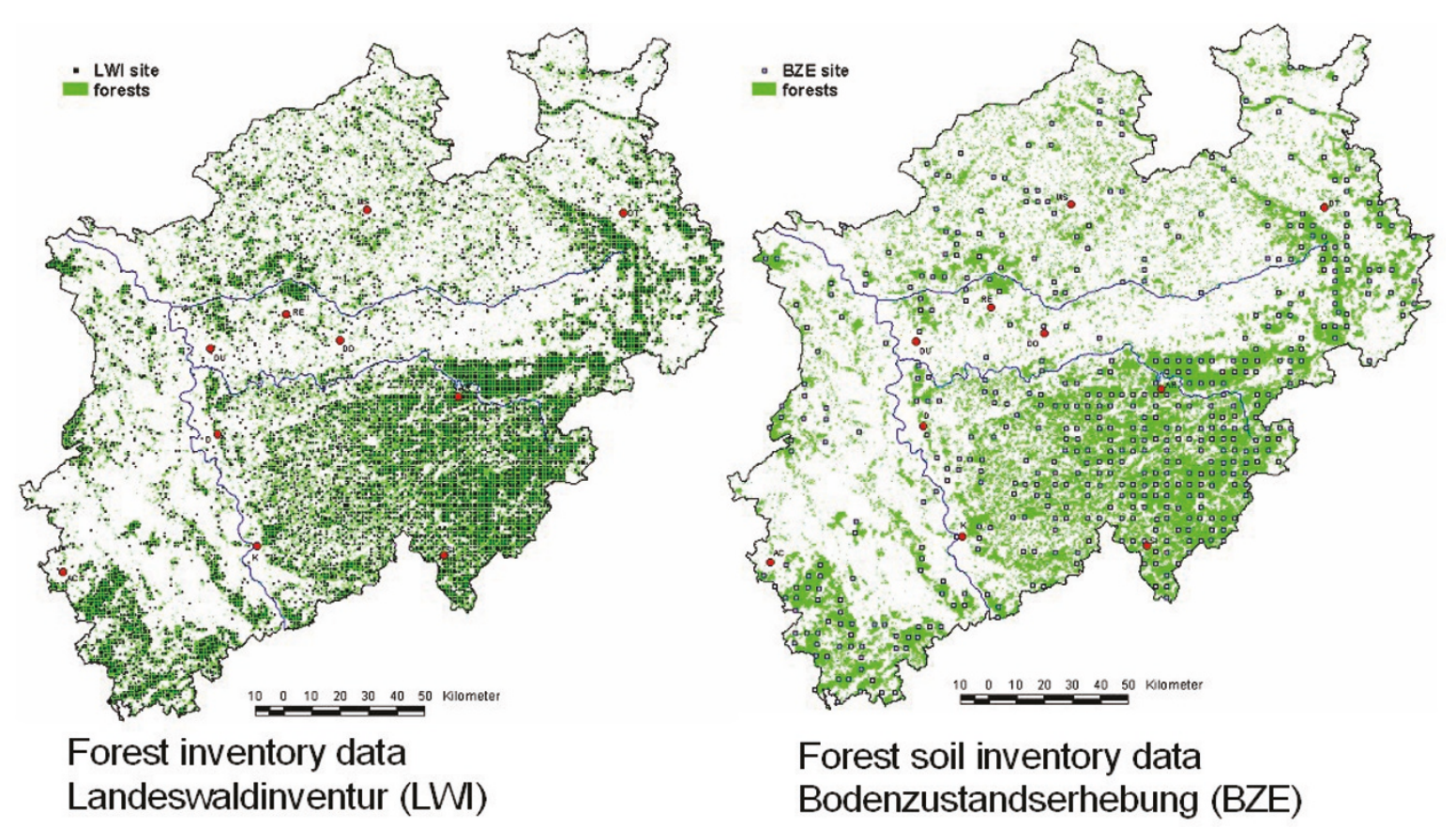

Figure 1 Forest inventory data used to spatially predict the C sequestration in forests of North Rhine-Westphalia.

possible influence of climatic variables, raster data in a resolution of $1 \times 1 \mathrm{~km}$ were provided by the German Weather Service (Deutscher Wetterdienst-DWD). The data included information on temperature estimates averaged annually and for the vegetation period (May to September) for the climate normal period 1961 to 1990. Accordingly, sums for global radiation, sunshine duration and precipitation were provided for the same time windows.

Since topography can be assumed to have significant impact on the $\mathrm{C}$ sequestration, different topographical indices were derived from a digital elevation model with a resolution of $30 \times 30 \mathrm{~m}$. The indices were calculated according to the approach introduced by [23] and adopted in the framework of the Forest Focus Programme for the calculation of $\mathrm{C}$ pools in the forests in the federal state Baden-Württemberg [24]. The following variables were derived by the elevation data: slope (between $0^{\circ}$ and $90^{\circ}$ ), slope length factor (according to the Universal Soil loss equation [25]), slope position index (relative position within a slope for defined radiuses-here 500, 750 and $1,000 \mathrm{~m}$ ), stream power index (characterised the degree of soil erosion due to down flowing water), topographic wetness index (depicting patterns of potential soil moisture), topographic position index (difference in topography within defined radiuses-here 500, 750 and 1,000 m), horizontal curvature (change of exposition per distance unit) and vertical curvature (change of slope per distance unit). All indices were calculated with help of ArcView GIS 3.3 including Spatial Analyst and other extensions (DEM Analysis Tool, TOPOCROP, Topographic Position Index).

\section{Methodology: GIS-mapping by use of regression kriging}

The methodology that was applied to map the $C$ storage in North Rhine-Westphalian forests is referred to as regression kriging (RK) (Figure 2). RK is a spatial interpolation technique that combines (linear) regression analysis with geostatistics. Geostatistical procedures are based on the theory of regionalised variables [26]. Accordingly, spatial measurements are seen as the realisation of a random function whose mean may either be constant (stationary process) or varying across the study area. In RK, this varying mean is accounted for in terms of surface maps available for the entire study area. These surface maps are calculated by at first analysing the association between the variable of interest (available for different locations) and a set of chosen potential influence factors (available for the entire study region) via linear regression analysis. Then, the derived regression functions are applied on available surface data to map the variable of interest throughout the study area.

Figure 1 depicts the way RK was used to map the $C$ storage in the humus layer, in the mineral soil and in the living forest trees/dead wood. At first, the punctual data on the $C$ storage were intersected with the available raster data on the predicting variables in a geographic information system (GIS). Next, stepwise multivariate 


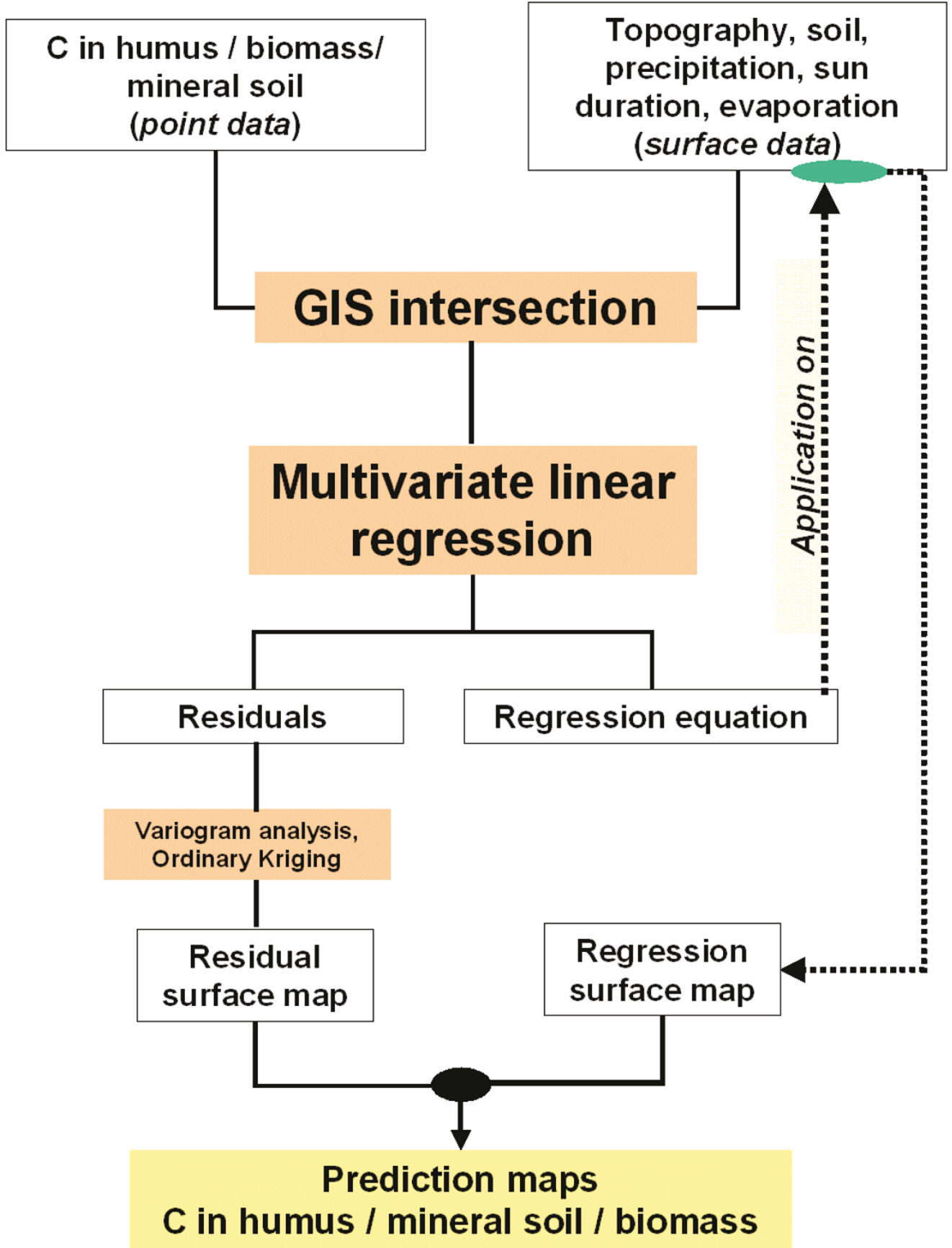

Figure 2 Methodological concept to predictively map C sequestration in North Rhine-Westphalian forests.

linear regression analysis was applied to determine and model the association between the target and predicting variables using SPSS 15.0. The resulting regression equations were then applied on the predicting variables to calculate state wide regression maps. Since the residuals of the regression model stand for the errors of the spatially varying random function they were investigated with regard to spatial autocorrelation. In geostatistics, such is most commonly examined and modelled by use of variogram analysis, in this case with help of the ArcGIS 9.3 extension Geostatistical Analyst. Accordingly, the mean squared differences of all pairs of residual values (semi-variances) were calculated for so called bins of a variogram map to derive an experimental semi-variogram. Variogram models were fitted to the experimental semi-variograms in terms of the least- 
squares method. The variogram model can be described by three parameters: range, sill and nugget effect. The range equals the maximum separation distance for which a distinct increase of semi-variogram values, and therefore spatial autocorrelation, can be observed. The sill corresponds to the semi-variance assigned to the range. Spatial variability within the first lag can be caused by measurement errors and other confounding factors resulting in high semi-variances. The magnitude of the nugget effect can be expressed by the ratio of nugget and sill (nugget/sill ratio). In case of a nugget/sill ratio of 1 , meaning a pure nugget effect, no spatial autocorrelation exists. Provided the residuals show spatial autocorrelation patterns they may be mapped with help of ordinary kriging and then added to the corresponding regression map.

Multivariate regression analyses comprised the following working steps [27]: Setting the framework for the regression model, estimation of the regression function, verification of the regression function and coefficients as well as verification of the underlying assumptions of the regression model. The statistical significance of the regression function was determined using $F$ statistics, all regression coefficients were verified by $t$ tests separately. The necessary assumptions of the regression model were investigated by performing the following steps: Checking for linear dependency between target and predicting variables with help of partial diagrams ${ }^{\mathrm{a}}$; investigating homoscedasticity and autocorrelation patterns of the residuals by visually plotting the residuals against the target variable; investigation of normality of the residuals by means of histogram plots; checking for co-linearities between the predictors using Pearson correlation analysis.

Since linear regression analysis assumes metrical scaled target and predicting variables, only numerical data could be included in the analyses. For some categorical data like land use type, the category of interest (e.g. coniferous forest) was extracted in terms of a binary variable (existent $=1$ or non-existent $=0$ ). Three ordinally scaled variables ecological wetness rank (three rank numbers), classified mean soil number (five rank numbers) and upper soil texture rank (nine rank numbers) were handled as metrically scaled values.

\section{Results}

Regarding the underlying assumptions of regression analysis, the dependencies between the $C$ storage in the humus layer, in the mineral soil and in the biomass on the one hand and the predicting variables on the other hand, all showed linear dependencies. Accordingly, the multivariate regression analyses resulted in the following three equations which were all proven to be statistically significant ( $F$ statistics; $\alpha=0.05$ ). The same holds true for all regression coefficients in terms of the $t$ tests results $(\alpha=0.05$; the corresponding $p$ values are given in brackets following the different predictors). Furthermore, the linear dependency between the $\mathrm{C}$ storage and all predicting variables were investigated visually by partial diagrams. In all cases, no severe deviations were detected from linear dependency. For each $\mathrm{C}$ storage regression, one partial diagram each is depicted as an example (Figure 3).

\section{1. $C$ sequestration in the humus layer}

$\mathrm{YH}=2.78+0.3 \times A-0.56 \times B-0.001 \times C+0.1 \times D-0.19 \times E-0.4 \times F-0.21 \times G-0.1 \times H$

with: $A=$ occurrence of deciduous forest $(p=0.001)$; $B=$ vertical curvature [degree per metre] $(p<0.001) ; C$ $=$ annual precipitation [millimetres] $(p=0.003) ; D=$ upper soil texture rank $(p<0.001)$; $E=$ ecological wetness rank $(p=0.001) ; F=$ slope position index $(p=$ $0.023)$, radius $500 \mathrm{~m} ; G=$ occurrence of coniferous forest $(p=0.027) ; H=$ annual mean temperature $\left[{ }^{\circ} \mathrm{C}\right](p<$ 0.039).

The linear regression model explains $19.5 \%$ of the variance of the dependent variable $\left(R^{2}=0.195\right)$. The depicted regression coefficients may not enable to assess the relevance of the predictors in the regression model because of their dependency on the range of the values of the corresponding predicting variable. Hence, they were standardised by multiplying each regression coefficients with the ratio of the standard deviation of the corresponding predicting variable and the variable of interest. Accordingly, the upper soil texture rank shows the strongest association to the $C$ storage in the humus layer $(\beta=0.22)$ followed by annual precipitation $(\beta=$ $0.18)$ and the incidence of deciduous forests $(\beta=0.17)$. Negative dependencies can be observed for vertical curvature $(\beta=-0.15)$, ecological wetness $\operatorname{rank}(\beta=-0.15)$, mean annual temperature $(\beta=-0.14)$, the incidence of coniferous forests $(\beta=-0.11)$ and the slope position index $(\beta=-0.10)$.

Due to proven heteroscedasticity in the residual plots the regression analysis was performed with the lognormally transformed data of the $C$ sequestration in the humus layer (Figure 4). The residuals then sufficiently approximated a normal distribution as can be seen by visual inspection of the histograms (Figure 5).

As can be seen in Table 1 the chosen predicting variables partly show significant correlations. Nevertheless, most of these correlations are extremely low. There are only two variable pairs that show higher correlation than $\rho=0.5$ (between mean annual temperature and annual precipitation sum: $\rho=-0.71$ and the occurrence of deciduous and coniferous forests). Since these correlations were still only moderate/moderately high, the corresponding variables were kept in the regression 

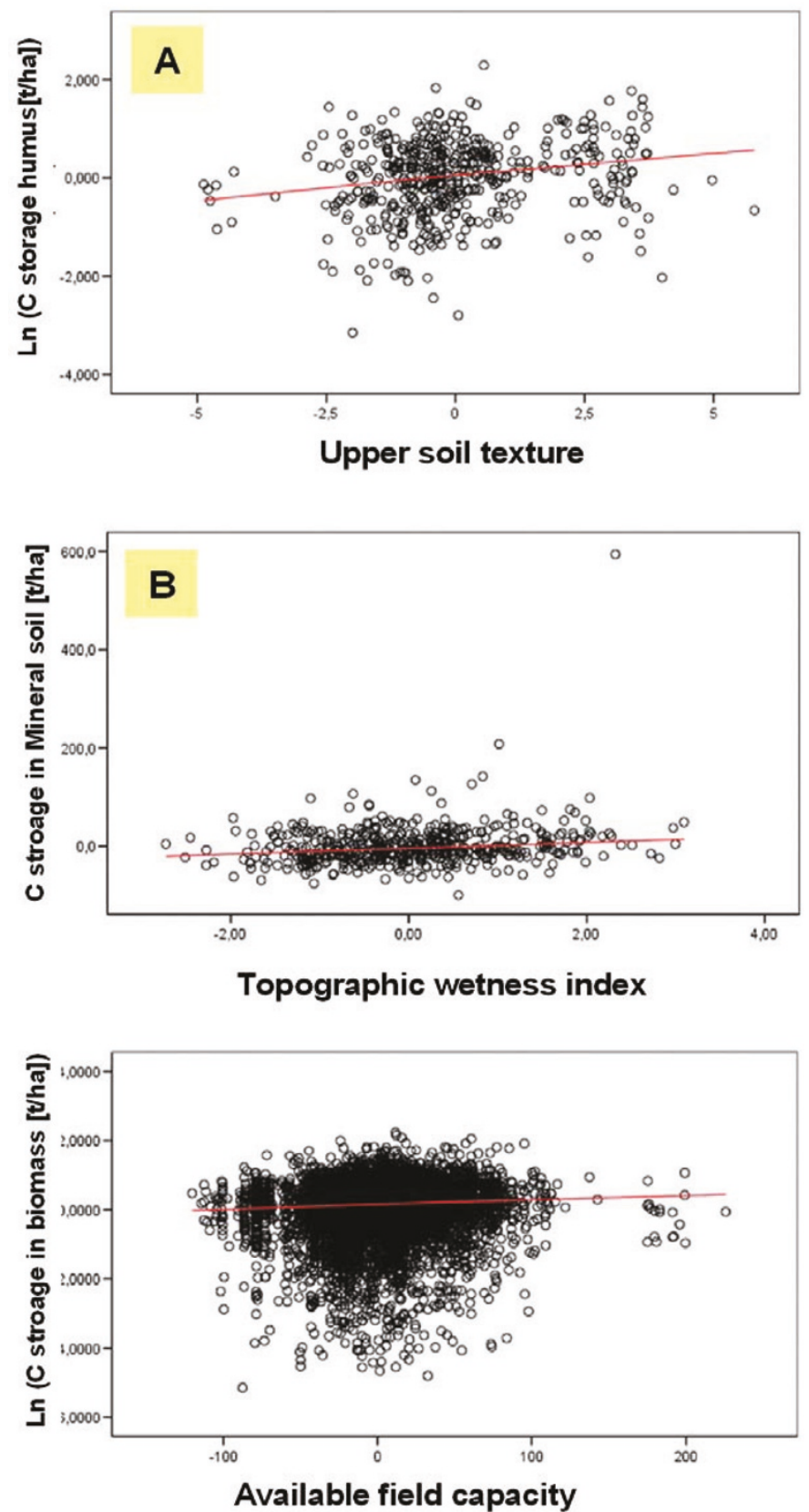

Figure 3 Examples of partial diagrams for the regression of the $\mathbf{C}$ storage. In humus (exemplified by the upper soil texture rank-A), in the mineral soil (topographical wetness index-B) and in forest trees/dead wood (available field capacity-C).

model. Apart from these two correlations the assumption of collinearity between the predicting variables could be accepted.

\section{2. $C$ sequestration in the mineral soil}

$\mathrm{YM}=24.32+8.83 \times A+6.89 \times B+0.03 \times C+0.04 \times D-9.72 \times E$

with $A=$ topographic wetness index $(p<0.001) ; B=$ thickness of upper soil texture rank [decimetre] $(p=$
0.005); $C=$ elevation [metre] $(p<0.013) ; D=$ cation exchange capacity [moles per square metre] $(p=0.042)$; $E=$ slope position index, radius $750 \mathrm{~m}(p=0.0499)$.

The linear regression model explains $9.2 \%$ of the variance of the dependent variable $\left(R^{2}=0.092\right)$. For the $\mathrm{C}$ storage in mineral soil, the topographic wetness index shows the highest standardised regression coefficient ( $\beta$ $=0.28$ ) followed by the thickness of the upper soil texture $\operatorname{rank}(\beta=0.15)$, elevation $(\beta=0.14)$, cation 

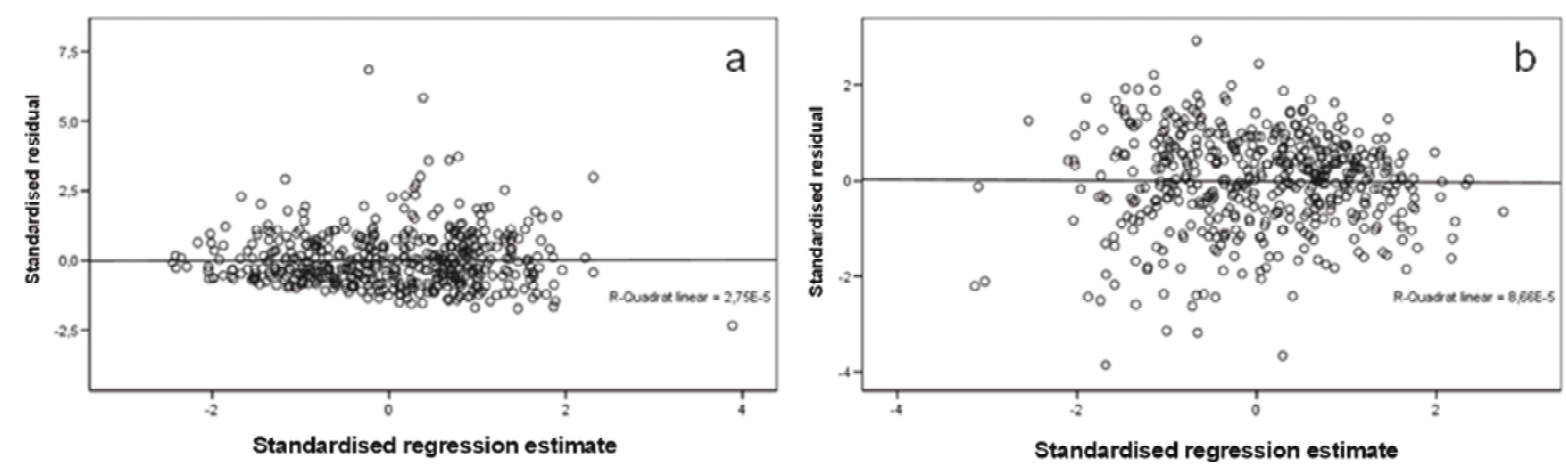

Figure 4 Residualplot for C storage in humus before (a) and after (b) lognormal transformation.

exchange capacity $(\beta=0.09)$ and the slope position index $(\beta=-0.09)$.

For the $\mathrm{C}$ sequestration in the mineral soil, the residuals of the regression model did not indicate heteroscedasticity (Figure 6) and were accepted to be normally distributed (as indicated in Figure 7). The regression analysis was therefore performed for the original values. Here, too, the chosen predicting variables show significant but mostly very low correlations (highest for the association between elevation and the topographical wetness index: $\rho=-0.55)$. The regression model was accepted to be used for the mapping of the $C$ storage in mineral soil for the forests of North Rhine-Westphalia.

\section{3. $C$ sequestration in the living forest trees/dead wood}

$\mathrm{YD}=4.66+0.000017 \times A+0.002 \times B-0.09 \times C-0.001 \times D+0.07 \times E-0.02 \times F-0.07 \times G$

with $A=$ annual sum global radiation [watts per square meter] $(p<0.001) ; B=$ available field capacity [millimetre] $(p<0.001)$; $\mathrm{C}=$ classified mean soil number $(p<0.001)$; $\mathrm{D}=$ saturated hydraulic conductivity [centimeters per day] $(p<0.001) ; \mathrm{E}=$ occurrence of coniferous forest $(p<0.001) ; \mathrm{F}=$ effective root depth [decimetre] $(p=0.001) ; \mathrm{G}=$ slope position index, radius $500 \mathrm{~m}(p=0.027)$.

The linear regression model explains $2.4 \%$ of the variance of the dependent variable $\left(R^{2}=0.024\right)$. Compared

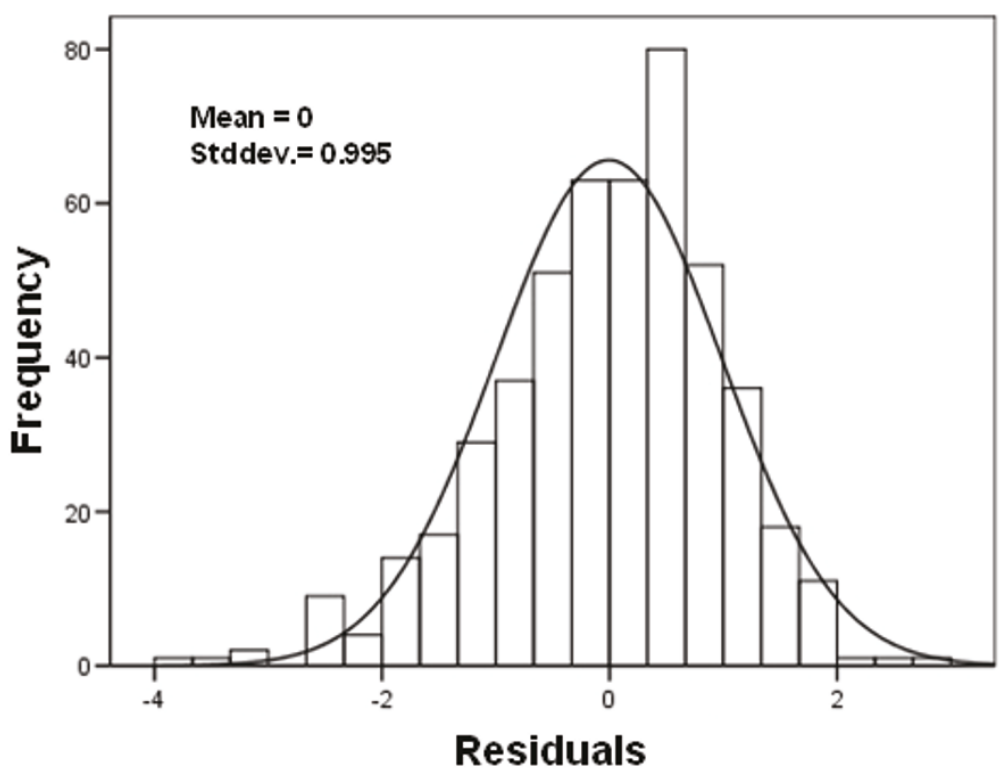

Figure 5 Histogram of the lognormally transformed data of the $C$ sequestration in the humus layer. 
Table 1 Coefficients of correlation (Pearson) for relevant predictors for C storage

\begin{tabular}{|c|c|c|c|c|c|c|c|c|c|}
\hline $\bar{A}$ & & $\begin{array}{l}\text { Deciduous } \\
\text { forest }\end{array}$ & $\begin{array}{l}\text { Coniferous } \\
\text { forest }\end{array}$ & $\begin{array}{c}\text { Vertical } \\
\text { curvature }\end{array}$ & $\begin{array}{c}\text { Annual } \\
\text { precipitation }\end{array}$ & $\begin{array}{c}\text { Upper soil } \\
\text { texture } \\
\text { rank }\end{array}$ & $\begin{array}{l}\text { Ecological } \\
\text { wetness } \\
\text { rank }\end{array}$ & $\begin{array}{l}\text { Annual mean } \\
\text { temperature }\end{array}$ & $\begin{array}{c}\text { Slope } \\
\text { position } \\
\text { index }\end{array}$ \\
\hline \multirow{2}{*}{$\begin{array}{l}\text { Deciduous } \\
\text { forest }\end{array}$} & $C_{p}$ & 1 & & & & & & & \\
\hline & $n$ & 498 & & & & & & & \\
\hline \multirow{2}{*}{$\begin{array}{l}\text { Coniferous } \\
\text { forest }\end{array}$} & $C_{p}$ & -0.568 & 1 & & & & & & \\
\hline & $n$ & 498 & 498 & & & & & & \\
\hline \multirow{2}{*}{$\begin{array}{l}\text { Vertical } \\
\text { curvature }\end{array}$} & $C_{p}$ & -0.070 & 0.011 & 1 & & & & & \\
\hline & $n$ & 497 & 497 & 497 & & & & & \\
\hline \multirow{2}{*}{$\begin{array}{l}\text { Annual } \\
\text { precipitation }\end{array}$} & $C_{p}$ & -0.237 & 0.228 & -0.028 & 1 & & & & \\
\hline & $n$ & 498 & 498 & 497 & 498 & & & & \\
\hline \multirow{2}{*}{$\begin{array}{l}\text { Upper soil } \\
\text { texture rank }\end{array}$} & $C_{p}$ & 0.021 & -0.018 & 0.045 & -0.389 & 1 & & & \\
\hline & $n$ & 497 & 497 & 496 & 497 & 497 & & & \\
\hline \multirow{2}{*}{$\begin{array}{l}\text { Ecological } \\
\text { wetness rank }\end{array}$} & $C_{p}$ & -0.035 & 0.060 & -0.054 & 0.326 & -0.117 & 1 & & \\
\hline & $n$ & 497 & 497 & 496 & 497 & 497 & 497 & & \\
\hline \multirow{2}{*}{$\begin{array}{l}\text { Annual mean } \\
\text { temperature }\end{array}$} & $C_{p}$ & 0.235 & -0.318 & 0.037 & -0.708 & 0.445 & -0.371 & 1 & \\
\hline & $n$ & 498 & 498 & 497 & 498 & 497 & 497 & 498 & \\
\hline \multirow{2}{*}{$\begin{array}{l}\text { Slope position } \\
\text { index }\end{array}$} & $C_{p}$ & 0.049 & -0.046 & 0.232 & 0.062 & -0.034 & 0.015 & 0.004 & 1 \\
\hline & $n$ & 496 & 496 & 496 & 496 & 495 & 495 & 496 & 497 \\
\hline B & & $\begin{array}{c}\text { Topographic } \\
\text { Wetness Index }\end{array}$ & $\begin{array}{c}\text { Thickness of } \\
\text { upper soil } \\
\text { texture }\end{array}$ & Elevation & $\begin{array}{l}\text { Cation } \\
\text { exchange } \\
\text { capacity }\end{array}$ & $\begin{array}{l}\text { Slope } \\
\text { position } \\
\text { index }\end{array}$ & & & \\
\hline \multirow{2}{*}{$\begin{array}{l}\text { Topographic } \\
\text { Wetness Index }\end{array}$} & $C_{p}$ & 1 & & & & & & & \\
\hline & $n$ & 497 & & & & & & & \\
\hline \multirow{2}{*}{$\begin{array}{l}\text { Thickness of } \\
\text { upper soil } \\
\text { texture }\end{array}$} & $C_{p}$ & 0.492 & 1 & & & & & & \\
\hline & $n$ & 497 & 498 & & & & & & \\
\hline \multirow[t]{2}{*}{ Elevation } & $C_{p}$ & -0.565 & -0.497 & 1 & & & & & \\
\hline & $n$ & 497 & 497 & 497 & & & & & \\
\hline \multirow{2}{*}{$\begin{array}{l}\text { Cation } \\
\text { exchange } \\
\text { capacity }\end{array}$} & $C_{p}$ & -0.128 & -0.090 & 0.110 & 1 & & & & \\
\hline & $n$ & 496 & 497 & 496 & 497 & & & & \\
\hline \multirow{2}{*}{$\begin{array}{l}\text { Slope position } \\
\text { index }\end{array}$} & $C_{p}$ & -0.161 & -0.209 & 0.146 & 0.077 & 1 & & & \\
\hline & $n$ & 494 & 494 & 494 & 493 & 495 & & & \\
\hline C & & $\begin{array}{l}\text { Annual sum } \\
\text { global } \\
\text { radiation }\end{array}$ & $\begin{array}{c}\text { Available field } \\
\text { capacity }\end{array}$ & $\begin{array}{c}\text { Classified } \\
\text { mean soil } \\
\text { number }\end{array}$ & $\begin{array}{l}\text { Saturated } \\
\text { hydraulic } \\
\text { conductivity }\end{array}$ & $\begin{array}{l}\text { coniferous } \\
\text { forest }\end{array}$ & $\begin{array}{l}\text { Effective root } \\
\text { depth }\end{array}$ & $\begin{array}{c}\text { Slope position } \\
\text { index }\end{array}$ & \\
\hline \multirow{2}{*}{$\begin{array}{l}\text { Annual sum } \\
\text { global radiation }\end{array}$} & $C_{p}$ & 1 & & & & & & & \\
\hline & $n$ & 8,779 & & & & & & & \\
\hline \multirow{2}{*}{$\begin{array}{l}\text { Available field } \\
\text { capacity }\end{array}$} & $C_{p}$ & -0.028 & 1 & & & & & & \\
\hline & $n$ & 8,762 & 8,771 & & & & & & \\
\hline
\end{tabular}


Table 1 Coefficients of correlation (Pearson) for relevant predictors for $\mathbf{C}$ storage (Continued)

\begin{tabular}{|c|c|c|c|c|c|c|c|c|}
\hline \multirow{2}{*}{$\begin{array}{l}\text { Classified mean } \\
\text { soil number }\end{array}$} & $C_{p}$ & -0.043 & 0.347 & 1 & & & & \\
\hline & $n$ & 8,762 & 8,771 & 8,771 & & & & \\
\hline \multirow{2}{*}{$\begin{array}{l}\text { Saturated } \\
\text { hydraulic } \\
\text { conductivity }\end{array}$} & $C_{p}$ & 0.122 & -0.281 & -0.270 & 1 & & & \\
\hline & $n$ & 8,740 & 8,745 & 8,745 & 8,748 & & & \\
\hline \multirow{2}{*}{$\begin{array}{l}\text { coniferous } \\
\text { forest }\end{array}$} & $C_{p}$ & -0.004 & 0.078 & 0.081 & -0.038 & 1 & & \\
\hline & $n$ & 8,751 & 8,742 & 8,742 & 8,728 & 8,758 & & \\
\hline \multirow{2}{*}{$\begin{array}{l}\text { Effective root } \\
\text { depth }\end{array}$} & $C_{p}$ & 0.008 & 0.737 & 0.150 & -0.355 & -0.002 & 1 & \\
\hline & $n$ & 8,762 & 8,771 & 8,771 & 8,745 & 8,742 & 8,771 & \\
\hline \multirow{2}{*}{$\begin{array}{l}\text { Slope position } \\
\text { index }\end{array}$} & $C_{p}$ & 0.017 & -0.011 & 0.005 & -0.028 & -0.015 & -0.004 & 1 \\
\hline & $n$ & 8,779 & 8,771 & 8,771 & 8,748 & 8,758 & 8,771 & 8,788 \\
\hline
\end{tabular}

In humus (A), in mineral soil (B) and in living forest trees/dead wood (C).

to the predicting variable for the $\mathrm{C}$ storage in the humus layer and the mineral soil the standardised regression coefficients are overall lower: Available field capacity $(\beta$ $=0.11)$, global radiation $(\beta=-0.10)$, the classified mean soil number $(\beta=-0.09)$, saturated hydraulic conductivity $(\beta=-0.07)$, incidence of coniferous forest $(\beta=0.04)$, effective root depth $(\beta=-0.06)$, slope position index $(\beta$ $=-0.02$ ).

As for the $C$ storage in the humus layer, signs of heteroscedasticity could be detected in the residual plot (Figure 8 ). The regression analysis was therefore performed with the lognormally transformed data. Still the residuals showed a slight skew to the left (Figure 9) but approximated a normal distribution sufficiently.

The Pearson correlations between all chosen predictors are depicted in Table 1. As can be seen, only in one case a correlation of above 0.5 exists (between the available field capacity and the effective root depth; $\rho=$ -0.737). The other correlations are mostly non significant and very low. The regression model was therefore accepted for the mapping.

Only for the residuals of regression model for the $\mathrm{C}$ sequestration in the humus layer spatial autocorrelation could be detected (nugget to sill ratio $=0.76$ ). Therefore ordinary kriging was applied to calculate a residual map for the study area.

To map the $C$ storage in humus layer, mineral soil and biomass, the corresponding regression equations were applied on the predicting variables in ArcView GIS 3.3. Regarding the $C$ storage in the humus layer the regression map was added to the calculated residual map. Finally, all three maps were summed up to one predictive map of the $\mathrm{C}$ storage in forests of North Rhine-Westphalia (Figure 10). Regarding the amount of stored $\mathrm{C}$ and the spatial differentiation the following can be observed: For the humus layer, 17.5 mio t $C$ were calculated for North Rhine-Westphalia, corresponding to ca. $20.3 \mathrm{t} \mathrm{C/ha}$. From the map in Figure 10 (upper

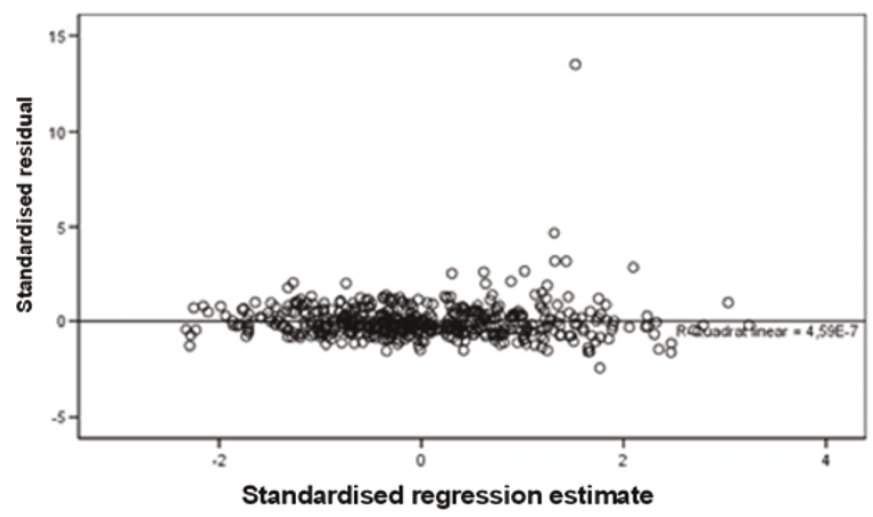

Figure 6 Residualplot for C storage in the mineral soil. 


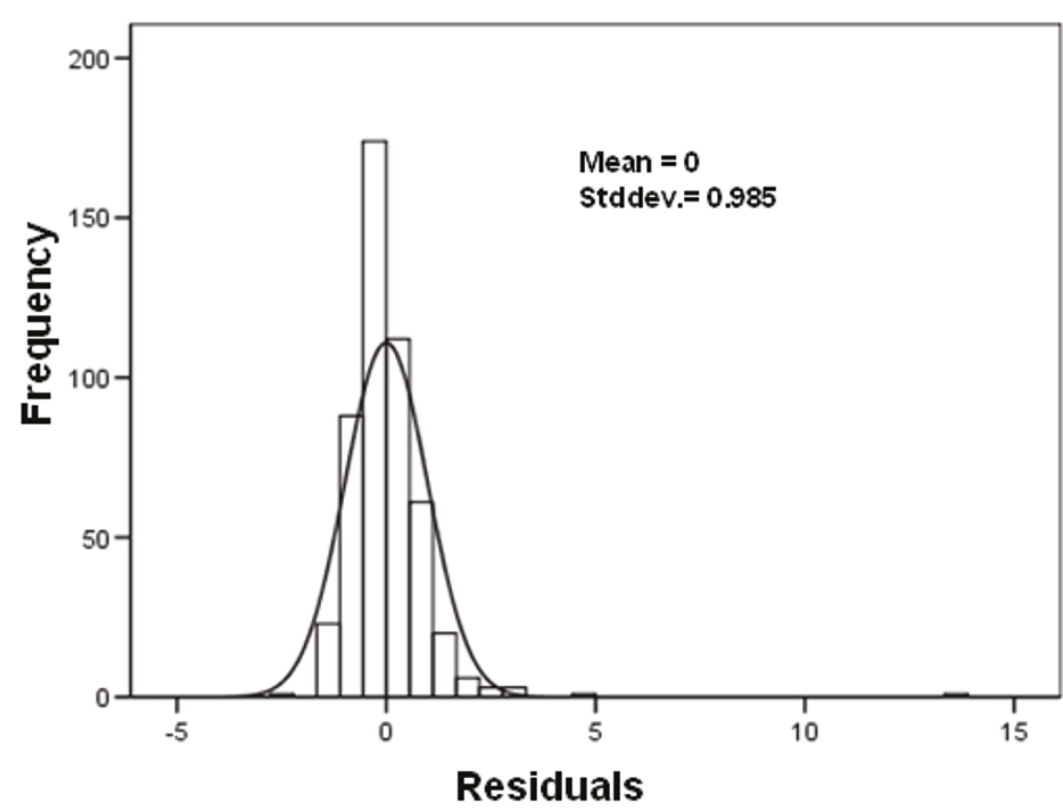

Figure 7 Histogram of the $C$ sequestration in the mineral soil.

left) it can be seen that high $C$ sequestration were estimated for the 'Sauerland', a natural landscape unit located in the low mountain ranges with a high coverage of forests, and the 'Westfälische Bucht', the most southern part of the northern lowlands. For the mineral soil, 81.5 mio t $\mathrm{C}$ were predicted $(93.7 \mathrm{t} \mathrm{C} / \mathrm{ha}$ ) with highest values in the eastern and northeastern part of the 'Westfälische Bucht' (Figure 10, middle left). The spatial patterns of the $\mathrm{C}$ storage in living trees/dead wood depict highest values in the low mountain ranges of North Rhine-Westphalia ('Bergisches Land', 'Sauerland', 'Weserbergland'-Figure 10, lower left). The analyses furthermore revealed that ca. 47.5 mio t $\mathrm{C}$ are stored in the biomass with relative values of $93.7 \mathrm{t} \mathrm{C/ha}$. In summary 147 mio t $C$ were predicted for the forests with help of regression kriging (54.7 t/ha; Figure 10, right).

\section{Discussion}

Comparing the results of the methodical approach presented in this article with those derived by a methodology applied to the same data [18], some differences can be observed: The $\mathrm{C}$ pools in the humus layer and in the mineral soil thereby only exhibit small differences $(1$ and $2.7 \mathrm{t}$ /ha less corresponding to $1.3 \%$ and $2.8 \%$, respectively). The difference in terms of the $\mathrm{C}$ sequestration in living trees/dead wood is higher (12.3 t/ha higher corresponding to $22.5 \%$ ). The reason for this might be that in the study mentioned above [18] additional categorical data was included in the decision tree analyses. The categorical data were chosen as the most significant splitting variables to subdivide the data sets for the $\mathrm{C}$ storage in the humus layer (categorical splitting variable: humus type), in living trees/dead wood (categorical
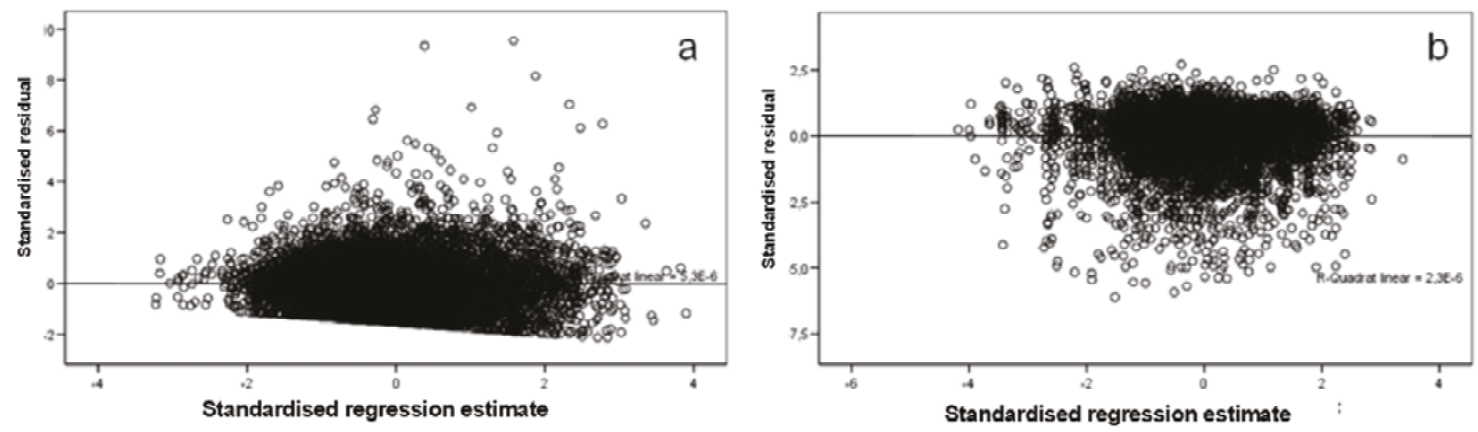

Figure 8 Residual plot C storage in forest trees/dead wood before (a) and after lognormal transformation (b). 


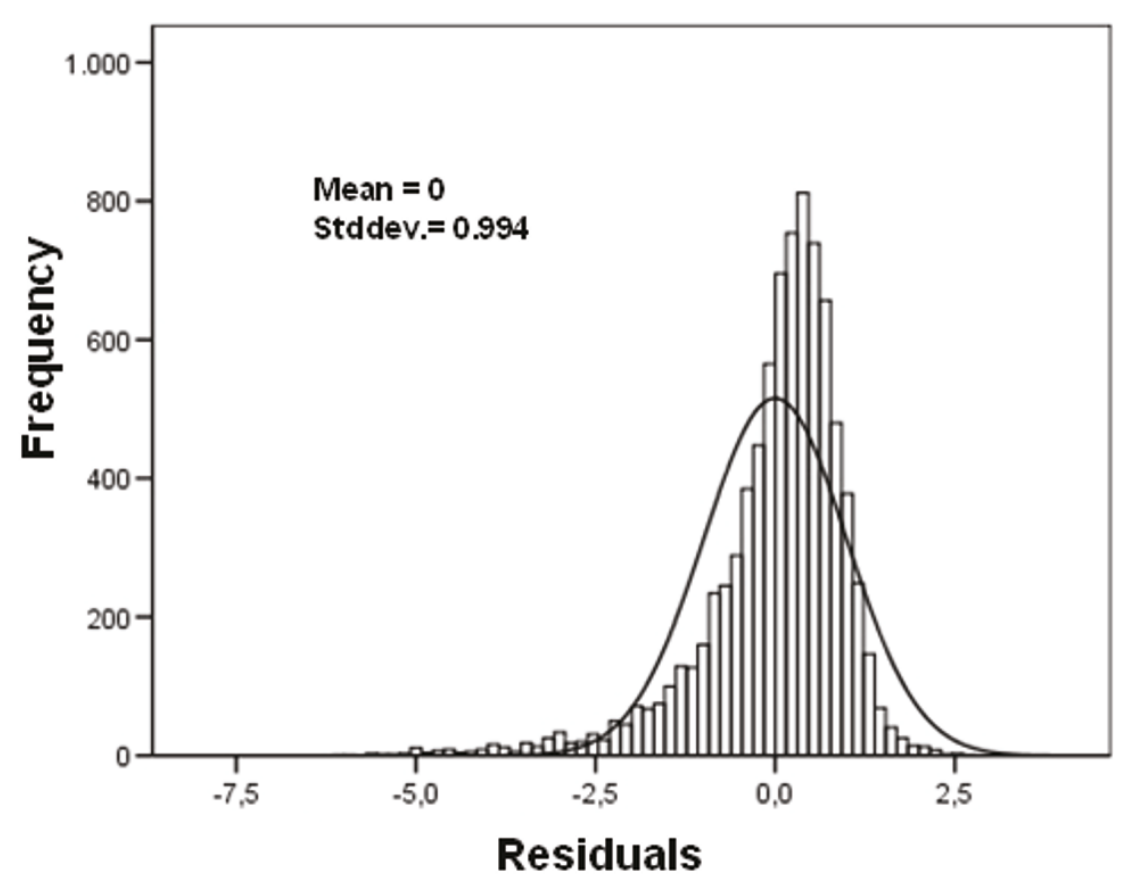

Figure 9 Histogram of the lognormally transformed data of the $\mathbf{C}$ sequestration. In the living forest trees/dead wood.

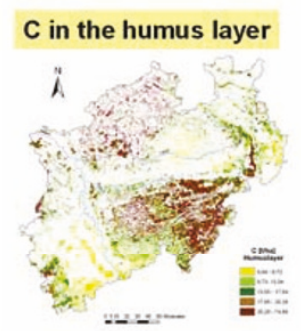

\section{C storage in forests}

C in the mineral soil
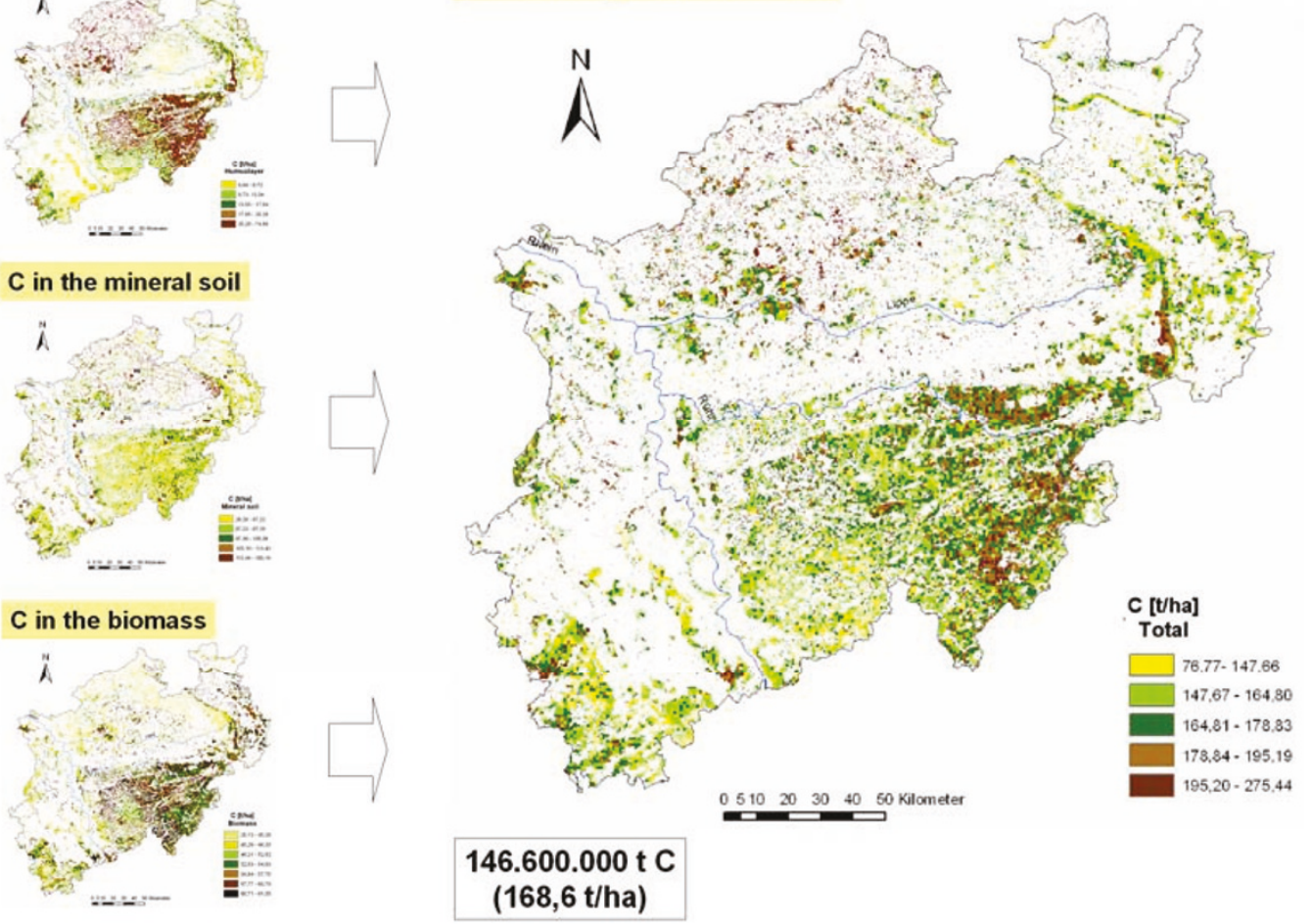

Figure $10 \mathrm{C}$ storage in humus, mineral soil, biomass (left) and in forests of North Rhine-Westphalia (right). 
splitting variable: forestral growth districts) and in the mineral soil (categorical splitting variable: soil type) into subclasses.

The primary basis for the results of this study rely on three regression equations enabling to predict the $\mathrm{C}$ storage to different degrees, reaching from $19.5 \%$ explained variance for the humus layer to $2.4 \%$ for the living forest trees/dead wood. This is in contrast to a comparative study [22-24] which used the same type of analyses and similar data to predict $C$ sequestration within several topographically unique units and the entire federal state of Baden-Württemberg. Like in the study at hand, data on climate (sun duration, temperature, precipitation) and soil were used. The latter contained parameters which were not available in this study, such as the ratio of different tree species within administrative forest units, the age of the forest stands and the type of soil treatment (e.g. liming activities). Like here, different topographical indices were calculated from a digital elevation map with a resolution of $25 \times 25 \mathrm{~km}^{2}$. The resulting regression models were able to explain $45.4 \%$ (mineral soil) and 64\% (humus layer) of the variance of the $C$ sequestration [24]. The reason the performance of our models were not as good might be caused by the insufficient availability of adequate data and/or factors that were not accounted for in the analysis. Another reason might be the data quality of both target and predictor variables: The $C$ storage in living forest trees and dead wood for example is estimated by multiplication of the volume of adequately large trees and the tree specific density [28]. Fifty percent of the resulting dry wood mass then is set as the value for the $\mathrm{C}$ sequestration, $\mathrm{C}$ in roots, leaves and needles as well as in the shrub layers are not included. One other possibility for the low degree of explained variance might have to do with temporal criteria and spatial scale effects: The climatic data were annually averaged for a time period of 30 years (1960 to 1990) which might be too long to account for the $\mathrm{C}$ sequestration. Furthermore, the climatic variables were provided in terms of $1 \times 1-\mathrm{km}^{2}$ raster data that were intersected with the punctual measurements on the $\mathrm{C}$ pools. These maps had been calculated by applying interpolation techniques on measurement data resulting in spatial generalisation effects. Similar holds true for the soil parameters that were taken from a vector map with a resolution of 1:50,000. This resolution might be too low in order to assess influences of soil characteristics (e.g. effective root zone, available field capacity, cation exchange capacity) on the $C$ sequestration measured at the sites of the LWI and BZE.

Compared to other national and international studies, the results at hand mostly show similar tendencies. According to [29] an average C storage of 96, $7 \mathrm{t} / \mathrm{ha}$ can be expected for the mineral soil and the humus layer in
North Rhine-Westphalia which is $17.8 \%$ lower than what was calculated in the investigation at hand. Scheffer [14] estimated about 183 mio t $C$ to be stored in the forests of North Rhine-Westphalia. The difference of 36 mio t $\mathrm{C}$ may be due to the fact that [14] summed up information on the $C$ storage in the root mass $(14.6 \mathrm{t} /$ ha), the herbaceous layer (1.1 t/ha) and the remains of the timber harvest $(76.8 \mathrm{t} / \mathrm{ha})$ together with the $\mathrm{C}$ storage of the living forest trees. $\mathrm{C}$ storage, $16.9 \mathrm{t} / \mathrm{ha}$ (15 mio $\mathrm{t}$ ), was calculated for the humus layer which lies 2.4 $\mathrm{t} /$ ha lower than estimated by lognormal kriging based on forest inventory data. For the mineral soil, they estimated $93.7 \mathrm{t} \mathrm{C} /$ ha which is $3 \mathrm{t} / \mathrm{ha}$ higher than in the study at hand. Baritz and Strich [30] calculated a mean $\mathrm{C}$ content in the humus layer of $20.7 \mathrm{t} \mathrm{C} / \mathrm{ha}$ for Germany which is slightly above the concentration calculated for the forests of North Rhine-Westphalia. In the same study a $\mathrm{C}$ average of $87.9 \mathrm{t} \mathrm{C} / \mathrm{ha}$ was calculated for the mineral soil down to a depth of $0.9 \mathrm{~m}$ which is very close to the 81.5 mio t $C$ calculated in this study. For the latter, the mineral soil layer was defined to a depth of $2 \mathrm{~m}$. [31] claim that the $C$ storage in mineral soils can highly differ due to different bedrocks: soils with calcareous bedrocks show the highest $C$ contents (115 t/ha) whereas pseudogleys influenced by stagnant water show the lowest values ( $47 \mathrm{t} / \mathrm{ha}$ ). Wirth et al. [32] found that the forests of Thuringia fix $27.7 \pm 8.1 \mathrm{t} \mathrm{C/ha}$ in the humus layer. The according $C$ sequestration was calculated for both deciduous (11.3 t/ha) and coniferous (34.0 t/ha) forests.

\section{Conclusions}

This article demonstrates that the methodology presented enables mapping the $\mathrm{C}$ pools in living forest trees/dead wood, the humus layer and the mineral soil. The spatial estimations outlined are in good accordance with statistical detailed estimations based on the same data but on another mapping technique [18] on the one hand and with rough estimations techniques on the other hand which, in contrast, did allow neither for spatial differentiation nor for mapping. The presented approach should be validated by use of German wide inventory data. Furthermore, $C$ sequestration should be modelled according to different climate change scenarios by combining statistical methods and the dynamic modelling tools like WASMOD [33].

The developed methodology refers to the Forest Focus demand for using biomonitoring methods for the identification, assessment and documentation of climate change impacts on the biosphere [34]. Biomonitoring is expected to provide politicians with information, documents and a basis for decision support to assess climate change impacts and it is possible to develop new and to evaluate the effectiveness of existing adaptive measures 
[35]. The term Climate Biomonitoring was recommended for biomonitoring methods that are able to indicate climate change effects, and thus, are indispensable for the early detection of changes in the biosphere. Climate biomonitoring preferably makes use of already existing monitoring systems and data collections [35].

From the estimation of primary production and $C$ sink in forests of the 25 member states of the European Union, it could be concluded that independent methods should to be used to estimate regional $C$ budgets. Confidence concerning the accuracy of such budgets should be given by convergence across methods. 'Ideally, several precise estimates obtained from independent methods should converge' [19] and performance of the models should be enhanced by accounting for factors that control regional variation in growth.

From this investigation, it can be concluded that the values for the statistically based predictions of the $\mathrm{C}$ storage in the humus layer, in the mineral soil and in the living forest trees/dead wood as calculated in this investigation are comparable to those published by [18] and as described above based on literature research. Furthermore, the presented approach enabled to map the $\mathrm{C}$ fixation objectively and transparently using available monitoring data and statistical methods. The application of statistics allows the assessment of the reliability of the predicted $\mathrm{C}$ contents and their spatial distribution. When assessing the future changes in forest SOC stocks two antagonistic effects of temperature rise have to be considered. Higher temperatures tend to result in a decrease of $\mathrm{C}$ fixation by speeding decomposition, whereas increases in litter input due to increasing net primary production and changing age-class structure will slow the loss of SOC. Smith et al. [36] assessed soil $\mathrm{C}$ change in European forests by applying the Rothamsted C model [37] on a $10 \times 10^{\prime}$ grid using climate data from four climate models on emission scenarios defined by the [1]. Mean SOC stocks to $30 \mathrm{~cm}$ depth were derived for each grid cell from the European Soils Bureau 1- $\mathrm{km}^{2}$ soils database [38], and data on changes in land use and technology were considered as well. They showed that under some conditions, $\mathrm{C}$ in forest soils will increase slightly $(0.1$ to $4.6 \mathrm{Gt})$ in Europe from 1990 to 2080. Whilst for one scenario, forest SOC stocks are predicted to decrease by $0.3 \mathrm{Gt}$. For cropland soils, there was an increase of SOC of 1 to $7 \mathrm{t} \mathrm{C} / \mathrm{ha}$, whereas for grassland soils SOC rises by 3 to $6 \mathrm{t} \mathrm{C/ha}$ [39]. Different national and Europe-wide studies on recent changes in soil $\mathrm{C}$ stocks give an inconsistent impression. Whereas [40] claim UK and Europe, as a whole, to be a net $\mathrm{CO}_{2}$ sink, [41] observed a mean loss of SOC of $0.6 \%$ per year. Other sampling studies in Europe have shown contrasting results, too, with some showing loss of SOC (Flemish cropland [42]), and others showing no loss of SOC (Danish cropland [43]; Austrian soils [44].

Besides local case studies covering only small parts of the environment or computer models using digital soil maps and leading to spatially coarse maps on SOC distribution $[36,39,45,46]$, the calculations presented here mediate between these two spatial approaches. Nevertheless, the statistical evaluation of these results reveals that much of the overall variability of the $C$ contents remains unexplained.

Due to advances in forest management practices, increased nitrogen deposition, and reduced acidification by air pollution (sulphur dioxide) and also increasing temperatures and atmospheric $\mathrm{CO}_{2}$ concentrations, the majority of forests in Europe are growing faster now than in the early twentieth century [2]. Projected climate change will result in a substantial shift in vegetation distribution and will affect distribution and the timing of both pests and pollinators, as well $[47,48]$. On the other hand, projected temperature increase will cause forest decline by droughts $[49,50]$ and increase the danger of forest fires leading to a larger area being burned, more ignitions and longer fire seasons [51-54]. These aspects have also taken into account when assessing the future capability $\mathrm{C}$ sequestration of forests.

Further, the projected climate change will accelerate the release of $\mathrm{CO}_{2}$ from the soil, contributing to higher concentrations in the atmosphere [40,41]. Mitigation measures to reduce the detrimental effect of higher temperatures combined with lower soil moisture on the amount of SOC are changes in land cover and adaptation of land-management practices to increase net primary production and reduce losses of aboveground biomass from decomposition $[36,39,40,55]$. Under given climatic conditions, grassland and forests tend to have higher stocks of organic $\mathrm{C}$ than arable land and are seen as net sinks for $C$ [56]. Adaptive measures on agricultural land use are changes in farming practices, such as a reduction in tilling or retaining crop residues after harvesting. The recent environmental conditions in combination with the type of silviculture that has been developed over the past 50 years can efficiently sequester $\mathrm{C}$ on timescales of decades. However, using wood as biofuel and hence shorter rotations in forestry could cancel out the benefits of $\mathrm{C}$ storage over the past five decades [57].

\section{Endnotes}

${ }^{a}$ With partial diagrams the association between the target variable and a specific predicting variable is investigated without including the effect of the other predicting variables on the target variable. 


\section{Authors' contributions}

Both authors read and approved the final manuscript. WS mainly focussed on the scientific background and the writing of the paper, RP mainly worked out the methodological design and the GIS mapping concept.

\section{Competing interests}

The authors declare that they have no competing interests.

Received: 18 November 2010 Accepted: 14 September 2011 Published: 14 September 2011

\section{References}

1. IPCC (Intergovernmental Panel on Climate Change): In Climate Change, 2007: The Physical Science Basis. Edited by: Solomon S, Qin D, Manning M, Chen Z, Marquis M, Averyt KB, Tignor M, Miller HL. New York: Cambridge University Press; 2007:; Contribution of Working Group I to the fourth assessment report of the Intergovernmental Panel on Climate Change.

2. EEA (European Environment Agency): Impacts of Europe's Changing Climate2008 Indicator-based Assessment Copenhagen; 2008, EEA Report 4/2008.

3. Englert C, Pesch R, Schmidt G, Schröder W: Analysis of spatially and seasonally varying plant phenology in Germany. In Geospatial Crossroads @ GI_Forum '08: Proceedings of the Geoinformatics Forum Salzburg. Edited by: Car A, Griesebner G, Strobl J. Heidelberg: Wichmann; 2008:81-89.

4. Menzel A, Jakobi G, Ahas R, Scheifinger $H$, Estrella N: Variations of the climatological growing season (1951-2000) in Germany compared with other countries. Int I Climatol 2003, 23:793-812.

5. Scheifinger $H$, Menzel A, Koch E, Peter C: Trends of spring time frost events and phenological dates in Central Europe. Theor App/ Climatol 2003, 74:41-51.

6. Walther GR, Post E, Convey P, Menzel A, Parmesan C, Beebee TJC Fromentin JM, Hoegh-Guldberg O, Bairlein F: Ecological responses to recent climate change. Nature 2002, 416:389-395.

7. Aerts R, Cornelissen JHC, Dorrepaal E: Plant performance in a warmer world: general responses of plants from cold, northern biomes and the importance of winter and spring events. Plant Ecol 2006, 82:65-77.

8. Dixon RK, Brown S, Houghton RA, Trexier MC, Wisniewski J: Carbon pools and flux of global forest ecosystems. Science 1994, 263:185-190.

9. Sitch S, Cox PM, Collins WJ, Huntingford C: Indirect radiative forcing of climate change through ozone effects on the land-carbon sink. Nature 2007, 448:791-795

10. Casalegno S, Amatulli G, Bastrup-Birk A, Houston T: Modelling Current and Future Distribution of European Forest Categories. Proceedings of the 6th European Conference on Ecological Modelling: Challenges for Ecological Modelling in a Changing World: Global Changes, Sustainability and Ecosystem Based Management. 27-30 November 2007 Trieste, Italy; 2007.

11. Joosten R, Schulte A: Kohlenstoff- und Energieholzpotenziale der Wälder in Nordrhein-Westfalen. In Weltforstwirtschaft nach Kyoto. Wald und Holz als Kohlenstoffspeicher und regenerativer Energieträger. Edited by: Schulte A, Böswald K, Joosten R. Aachen, Shaker; 2001:123-136, [Berichte aus der Holzund Forstwirtschaft].

12. Apps MJ, Kurz WA, Beukema SJ, Bhatti JS: Carbon budget of the Canadian forest product sector. Environ Sci Pol 1999, 2:25-41.

13. Environment Canada: National inventory report, 1990-2004. Greenhouse gas sources and sinks in Canada. Environment Canada Inquiry Centre, Gatineau; 2006 [http://www.ec.gc.ca/pdb/ghg/inventory_report/ 2004_report_e.pdf].

14. Scheffer F: Lehrbuch der Bodenkunde Heidelberg: Spektrum Akademischer Verlag; 2002.

15. Tate RL: Soil Organic Matter: Biological and Ecological Effects New York: Wiley; 1987.

16. Quideau SA: Organic matter accumulation. Encyclopedia of Soil Science New York: Marcel Dekker Inc; 2002, 891-894.

17. Profft I, Mund M, Weber G-E, Weller E, Schulze E-D: Forest management and carbon sequestration in wood products. Eur J Forest Res 2009, 128:399-413.

18. Schröder W, Schmidt G, Pesch R: Großräumige Regionalisierung der Kohlenstoffbindung in Wäldern Nordrhein-Westfalens. Umweltwiss Schadst Forsch 2009, 21:515-526.

19. Luyssaert S, Ciais P, Piao SL, Schulze E-D, Jung M, Zaehle S, Schelhaas MJ, Reichstein M, Churkina G, Papale D, Abril G, Beer C, Grace J, Loustau D, Matteucci G, Magnani F, Nabuurs GJ, Verbeeck H, Sulkava M, Van Der
Werf GR, Janssens IA, members of the CARBOEUROPE-IP Synthesis Team: The European carbon balance. Part 3: Forests. Global Change Biol 2010, 16:1429-1450

20. Hengl T, Heuvelink GBM, Rossiter DG: About regression-kriging: from equations to case studies. Computers and Geosciences 2007, 33:1301-1315.

21. Odeh IOA, McBratney AB, Chittleborough DJ: Further results on prediction of soil properties from terrain attributes: heterotopic cokriging and regression-kriging. Geoderma 1995, 67:215-226.

22. Zirlewagen $D$, von Wilpert K: Upscaling of Environmental Information: Support of Land-Use Management Decisions by Spatio-Temporal Regionalization Approaches. Environmental Management 2010, 46:878-893.

23. Zirlewagen D: Regionalisierung bodenchemischer Eigenschaften in topographisch stark gegliederten Waldlandschaften Freiburg; 2003, [Freiburger Forstliche Forschung 19].

24. Zirlewagen D, von Wilpert K: Regionalisierung von Bodenkohlenstoffvorräten auf Forstamtsebene in Flachlandschaften Forest Focus Abschlussbericht. Freiburg, Recklinghausen; 2007.

25. Wischmeier W, Smith D: Predicting Rainfall Erosion Loss: A Guide to Conservation Planning United States Department of Agriculture. Washington; 1978, [Agriculture Handbook, 537].

26. Matheron G: Les Variables Regionalisées et leur Estimation Paris; Masson; 1965.

27. Backhaus K, Erichson B, Plinke W, Weiber R: In Multivariate Analysemethoden: eine anwendungsorientierte Einführung. Volume 11. überarb. Aufl., Springer. Berlin; 2006

28. Knigge W, Schulz H: Grundriss der Forstbenutzung. Entstehung,. Eigenschaften, Verwertung und Verwendung des Holzes und anderer Forstprodukte Verlag Paul Parey, Hamburg und Berlin; 1966.

29. Baritz R: Kohlenstoffvorräte in Waldböden Deutschlands Eberswalde; 1998, [Arbeitsbericht des Instituts für Forstökologie und Walderfassung Nr. 98/1].

30. Baritz R, Strich S: Forests and the national greenhouse gas inventory of Germany. Biotec, Agron, Soc Environ 2000, 4:267-271.

31. Baritz R, Rovira P, Romanya J, Erlandsson M, Van Ranst E, Zirlewagen D, Jandl R, Seufert G, Olsson M: Multi-source Inventory Methods for Quantifying Carbon Stocks and Stock Changes in European Forests. Carbolnvent: Validated, Representative Soil Carbon Profiles under Forest Vegetation Graz; 2005, Part I Final Report D3.1, Doc. No WP3-D3.1-RUG, Issue/Rev. 2.0.

32. Wirth C, Schulze ED, Schwalbe G, Tomczyk S, Weber G-E, Weller E, TLWJF in Zusammenarbeit mit dem Max-Planck-Institut für Biogeochemie, Jena: Dynamik der Kohlenstoffvorräte in den Wäldern Thüringens. Abschlussbericht zur 1. Phase des BMBF-Projektes 'Modelluntersuchung zur Umsetzung des Kyoto-Protokolls' Jena, Gotha; 2004, [Mitteilungen Thüringer Landesanstalt für Wald, Jagd und Fischerei, 23].

33. Rinker A, Deunert F, Schröder W: Im Spiegel des Klimawandels - Phosphor und Stickstoff in Böden Schleswig-Holsteins bei steigenden Lufttemperaturen. Umweltwiss Schadst Forschung 2009, 21:292-305.

34. BMU (Bundesministerium für Umwelt), Naturschutz und Reaktorsicherheit: Deutsche Anpassungsstrategie an den Klimawandel Berlin; 2008 [http://www. bmu.de/files/pdfs/allgemein/application/pdf/das_gesamt_bf.pdf].

35. Gebhardt H, Rammert U, Schröder W, Wolf H: Klima-Biomonitoring: Nachweis des Klimawandels und dessen Folgen für die belebte Umwelt. Umweltwiss Schadst Forsch 2010, 22:7-19.

36. Smith P, Smith J, Wattenbach M, Meyer J, Lindner M, Zaehle S, Hiederer R, Jones RJA, Montanarella L, Rounsevell M, Reginster I, Kankaanpaa S: Projected changes in mineral soil carbon of European forests, 19902100. Can J Soil Sci 2006, 86:159-169.

37. Coleman K, Jenkinson DS: Rothc-26.3-a model for the turnover of carbon in soil. In Evaluation of Soil Organic Matter Models Using Existing, Long-Term Datasets. Edited by: Powlson DS, Smith P, Smith JU. Springer: Heidelberg; 1996:237-246, [NATO ASI Series I, Vol. 38].

38. Jones RJA, Hiederer R, Rusco E, Montanarella L: Estimating organic carbon in the soils of Europe for policy support. Europ J Soil Sci 2005, 56:655-671.

39. Smith J, Smith P, Wattenbach M, Zaehle S, Hiederer R, Jones RJA, Montanarella L, Rounsevell MDA, Reginster I, Ewert F: Projected changes in mineral soil carbon of European croplands and grasslands, 1990-2080. Global Change Biol 2005, 11:2141-2152.

40. Janssens IA, Freibaur A, Schlamadinger B, Ceulemans R, Ciais P, Dolman AJ, Heimann M, Nabuurs GJ, Smith P, Valentin R, Schulze ED: The carbon budget of terrestrial ecosystems at country-scale-a European case study. Biogeosci 2005, 2:15-26. 
41. Bellamy PH, Loveland PJ, Bradley R: Carbon losses from all soils across England and Wales 1978-2003. Nature 2005, 437:245-248.

42. Sleutel S, De Neve S, Hofman G: Estimates of carbon stock changes in Belgian cropland. Soil Use \& Manage 2003, 19:166-171.

43. Heidmann T, Christensen BT, Olesen SE: Changes in soil C and N content in different cropping systems and soil types. In Greenhouse Gas Inventories for Agriculture in the Nordic Countries. Edited by: Petersen SO, Olesen JE. Ministry of Food, Agriculture and Fisheries, Danish Institute of Agricultural Sciences, Foulum, Denmark; 2002:77-86

44. Dersch G, Boehm K: Beiträge des Bodenschutzes zum Schutz der Atmosphäre und des Weltklimas. In Bodenschutz in Österreich. Edited by: Blum WEH, Klaghofer E, Loechl A, Bundesamt RP. Forschungszentrum für Landwirtschaft. Wien, Österreich; 1997:411-432.

45. Jung M, Le Maire G, Zaehle S, Luyssaert S, Vetter M, Churkina G, Ciais P, Viovy N, Reichstein M: Assessing the ability of three land ecosystem models to simulate gross carbon uptake of forests from boreal to Mediterranean climate in Europe. Biogeosci 2007, 4:647-656.

46. Zaehle S, Bondeau A, Carter TR, Cramer W, Erhard M, Prentice IC, Reginster I, Roundsevell MDA, Stitch S, Smith B, Smith PC, Sykes M: Projected changes in terrestrial carbon storage in Europe under climate and land-use change, 1990-2100. Ecosystems 2007, 10:380-401.

47. Desprez-Loustau M-L, Marcais B, Nageleisen L-M, Piou D, Vannini A: Interactive effects of drought and pathogens in forest trees. Ann of Forest Sci 2006, 63:597-612.

48. Lucht W, Schaphoff S, Erbrecht T, Heyder U, Cramer W: Terrestrial vegetation redistribution and carbon balance under climate change. Carbon Balance Manage 2006, 1:1-7.

49. Breda N, Huc R, Granier A, Dreyer E: Temperate forest trees and stands under severe drought: a review of ecophysiological responses, adaptation processes and long-term consequences. Ann Forest Sci 63:625-644.

50. Peñuelas J, Lloret F, Montoya R: Severe drought effects on Mediterranean woody flora in Spain. Forest Sci 2001, 47:214-218.

51. Allen CD: Cross-scale interactions among forest dieback, fire, and erosion in northern New Mexico landscapes. Ecosystems 2007, 10:797-808.

52. Flannigan MD, Amiro BD, Logan KA, Stocks BJ, Wotton BM: Forest fires and climate change in the 21st Century. Mitig Adapt Strateg Glob Change 2005, 11:847-859.

53. Gillett NP, Weaver AJ, Zwiers FW, Flannigan MD: Detecting the effect of climate change on Canadian forest fires. Geophys Res Letters 2004, 31, L18211.

54. Soja AJ, Tchebakova NM, French NHF, Flannigan MD, Shugart HH, Stocks BJ, Sukhinin Al, Parfenova El, Chapin FS III, Stackhouse PW Jr: Climate-induced boreal forest change: Predictions versus current observations. Glob Planet Change 2007, 56:274-296.

55. Liski J, Perruchoud D, Karjalainen : Increasing carbon stocks in the forest soils of Western Europe. Forest Ecol Manage 2002, 169:159-175.

56. Vleeshouwers LM, Verhagen A: Carbon emissions and sequestration by agricultural land use: a model study for Europe. Global Change Biol 2002, 8:519-530.

57. Ciais P, Schelhaas MJ, Zaehle S, Piao SL, Cescatti A, Liski J, Luyssaert S, LeMaire G, Schulze ED, Bouriaud O, Freibauer A, Valentini R, Nabuurs GJ: Carbon accumulation in European forests. Nature Geosci 2008, 1:425-429.

doi:10.1186/2190-4715-23-31

Cite this article as: Schröder and Pesch: Mapping carbon sequestration in forests at the regional scale - a climate biomonitoring approach by example of Germany. Environmental Sciences Europe 2011 23:31.

\section{Submit your manuscript to a SpringerOpen ${ }^{\mathcal{O}}$ journal and benefit from:}

- Convenient online submission

- Rigorous peer review

- Immediate publication on acceptance

- Open access: articles freely available online

- High visibility within the field

- Retaining the copyright to your article

Submit your next manuscript at $\gg$ springeropen.com 